\title{
PERANAN ADAPTIVE ITERATIVE DOSE REDUCTION 3D (AIDR 3D) DALAM MENINGKATKAN KUALITAS CITRA MSCT ABDOMEN
}

\author{
Nur Ainiyah ${ }^{1}$ Sigit Wijokongko ${ }^{2}$ Nanang Sulaksono ${ }^{3}$ \\ ${ }^{1}$ RSUD Dr. Saiful Anwar Malang \\ ${ }^{2} R S$ Tugurejo Semarang \\ ${ }^{3}$ Poltekkes Kemenkes Semarang \\ Corresponding author: Nur Ainiyah \\ e-mail: ainiyaeni79@gmail.com
}

\begin{abstract}
Background: Abdominal MSCT has better sensitivity and specificity, however its radiation exposure is high. Adaptive Iterative Dose Reduction (AIDR) 3D is an iterative reconstruction technology on Toshiba which produces a better image quality by reducing noise and streak artifacts in low dose. Based on author's observation, abdominal MSCT performed at the hospital uses a standard routine abdominal MSCT protocol without adjusting the level of AIDR 3D. AIDR 3D has several strength level allowing an optimal image quality. This study was aimed to explain the role of AIDR 3D in improving the image quality and radiation dose of abdominal MSCT.

Methods: This research method is descriptive with the literature study approach, by collecting articles from ProQuest, Google Scholar, PubMed, SpringerLink, and ScienceDirect about the role of AIDR 3D on abdominal MSCT published 2013-2020. The articles were selected according to the inclusion criteria. So there were 4 relevant journals which were then analyzed by making a journal summary, evaluating, giving opinions so that conclusions and suggestions can be drawn.

Result: The results showed that AIDR 3D can improve the image quality of abdominal MSCT by reducing noise, artifacts and increasing CNR, SNR, image sharpness. Noise reduction and CNR increase, the most prominent SNR is found in AIDR 3D Strong, followed by Standard and Mild. AIDR 3D can reduce radiation doses better without reducing image quality

Conclusion: AIDR 3D can improve image quality on abdominal MSCT and the use of integrated AIDR 3D SUREExposore 3D can reduce radiation doses better without reducing image quality. Reduction of radiation dose between $23 \%$ to $76 \%$.
\end{abstract}

Keyword : AIDR 3D, Image Quality, Radiation Dose, Abdominal MSCT

\section{Pendahuluan}

Pada MSCT abdomen untuk membedakan jaringan normal dan kelainan patologi diperjelas dengan penambahan media kontras dan dapat dilakukan dengan MSCT abdomen singlephase atau multiphase (fase arteri, fase vena, dan fase delay). Penggunaan MSCT abdomen ini akan menambah informasi diagnostik juga menambah paparan radiasi kepada pasien karena dilakukan scanning beberapa kali (Lampignano \& Kendrick, 2018). Pemeriksaan MSCT abdomen memiliki tingkat sensitivitas dan spesifisitas yang lebih baik, akan tetapi kekurangannya adalah adanya paparan radiasi yang yang tinggi yaitu dosis radiasi efektif kumulatifnya lebih dari dua pertiga dari seluruh pencitraan diagnostik. Paparan radiasi dengan dosis efektif kumulatif yang tinggi sangat merugikan pasien dan meningkatkan kekhawatiran terhadap efek bahaya dari dosis radiasi yang diterima oleh pasien dan tenaga kesehatan lainnya (Scharf dkk., 2017).

Pengurangan dosis radiasi atau penurunan paparan radiasi akan menghasilkan peningkatan noise pada teknik rekonstruksi citra Filtered Back Projection (FBP), sehingga akan menghasilkan kualitas citra yang rendah. Semakin meningkatnya noise kualitas citra menjadi turun, dan sebaliknya 
semakin rendah noise maka kualitas citra semakin meningkat (Seeram, 2016).

Seiring dengan perkembangan MSCT, kekhawatiran tentang paparan radiasi telah meningkatkan perhatian untuk mengurangi dosis radiasi, namun mengakibatkan noise citra yang meningkat dan kualitas citra menurun, karena keterbatasan standar rekonstruksi algoritma Filtered Back Projection (FBP) yang saat ini digunakan pada samua MSCT. Metode untuk menurunkan noise telah dikembangkan berdasarkan rekonstruksi algoritma iterative (Matsuki dkk., 2013).

Baru-baru ini, berbagai algoritma rekonstruksi berulang telah diperkenalkan. Beberapa algoritma rekonstruksi berulang tersedia terutama bekerja dalam domain data gambar, seperti Adaptive Statistical Iterative Reconstruction (ASIR) dan Iterative Reconstruction in Image Space (IRIS). Selain itu, ada juga rekonstruksi berulang yang dominan bekerja di domain raw data, seperti Sinogram-Affirmed Iterative Reconstruction (SAFIRE), Hybrid Iterative Reconstruction (HIR), dan Adaptive Iterative Dose Reduction (AIDR) 3D (Nikolaou dkk., 2019).

Adaptive Iterative Dose Reduction (AIDR) 3D merupakan teknologi rekonstruksi iterative yang terdapat pada Toshiba yang didesain terintegrasi dengan Automatic Exposure Control (AEC) yang bisa memperbaiki kualitas citra dengan menurunkan noise dan streak artifact (Toshiba, 2012). Proses rekonstruksi AIDR 3D menggabungkan raw data dan optimasi noise di image space. Meskipun AIDR 3D didesain otomatis untuk memilih parameter yang sesuai jenis pemeriksaan, radiografer dapat memilih secara manual karena AIDR 3D memiliki level kekuatan yang bisa dipilih Mild, Standard, Strong. Level AIDR 3D mempunyai tingkat strength, semakin strength semakin tinggi noise filternya. Pengaturan standard direkomendasikan untuk sebagian besar protokol, akan tetapi semua pengaturan yang tersedia untuk tujuan penelitian (Toshiba, 2012).

Menurut Penelitian Chen dkk. (2016), dengan membandingkan rekonstruksi algorithma (FBP, AIDR 3D level mild, standard, dan strong) pada MSCT abdomen hasilnya menunjukkan rekonstruksi AIDR 3D dengan level strong bisa mengurangi dosis $72 \%$ pada phantom dan $47,1 \%$ pada pasien daripada dengan menggunakan rekonstruksi algoritma FBP, perbedaan ini dikarenakan atenuasi obyek yang berbeda. Pada level strong didapatkan noise terendah dan Signal to Noise Ratio (SNR) tertinggi dibandingkan dengan rekonstruksi algoritma FBP maupun variasi AIDR 3D lainnya. Ketajaman citra dari FBP signifikan berbeda dari variasi level AIDR 3D, sehingga kualitas citra dari AIDR 3D signifikan lebih menguntungkan daripada FBP.

Penelitan yang dilakukan Kim dkk. (2014) bahwa AIDR 3D signifikan mengurangi noise daripada dengan FBP dan meningkatkan SNR dan Contrast to Noise Ratio (CNR) dengan memperbaiki kualitas citra. Ketika rekonstruksi algoritma yang paling kuat digunakan maka peningkatan SNR dan CNR paling besar serta pengurangan noise. Pengaruh reduksi noise dari AIDR 3D secara signifikan lebih besar pada phantom dengan ukuran yang lebih besar daripada ukuran yang lebih kecil.

Penelitian yang dilakukan Yoon dkk. (2014) bahwa penerapan AIDR 3D pada Akuisisi Halfdose dapat dicapai pada pasien berukuran kecil tanpa menghambat kinerja diagnostik, sementara itu dapat meningkatkan kinerja diagnostik pada pasien berukuran sedang dan besar tanpa meningkatkan dosis radiasi. Noise, kualitas citra, dan konsesi lesi pada kelompok akuisisi Half-dose setara dengan FBP pada akuisisi Full-dose setelah menerapkan AIDR 3D di semua phantom. Dalam phantom yang berukuran kecil, kelompok akuisisi Half-dose direkonstruksi dengan AIDR 3D menunjukkan sensitivitas yang sama dalam memvisualisasikan kontras rendah pada Focal Liver Lesion (FLLs) daripada dengan FBP pada akuisisi Full-dose. Dalam phantom berukuran sedang dan besar, AIDR 3D mengurangi jumlah FLL kontras rendah yang hilang.

Penelitan yang dilakukan Nakamoto dkk. (2013) bahwa AIDR 3D mengurangi noise citra objekif dan meningkatkan CNR daripada dengan FBP di semua pengaturan $\mathrm{kVp}$ dan $\mathrm{mA}$. Di antara preset AIDR 3D, Strong paling menonjol dalam pengurangan noise citra, diikuti oleh Standard dan Mild. Pada pengaturan $120 \mathrm{kVp}$, noise citra objektif dan kualitas citra subjektif pada $100 \mathrm{~mA}$ dengan AIDR 3D Strong setara dengan akuisisi 400mA dengan FBP. Hasil ini menunjukkan bahwa menggunakan AIDR 3D dapat memungkinkan pengurangan dosis radiasi hingga 75\% dengan mempertahankan noise citra yang dapat diterima pada pengaturan $120 \mathrm{kVp}$. Pada pengaturan $80 \mathrm{kVp}$, kualitas citra subyektif pada $400 \mathrm{~mA}$ dengan AIDR 3D Strong setara dengan akuisisi 580mA dengan FBP, meskipun noise citra objektif pada $200 \mathrm{~mA}$ dengan AIDR 3D Strong setara dengan akusisi pada 580mA dengan FBP. 
Dengan demikian, pengurangan dosis pada pengaturan $80 \mathrm{kVp}$ akan tetap pada 31-66\%. Pada pengaturan $\mathrm{kVp}$ yang lebih rendah, jumlah noise citra meningkat secara nyata ketika arus tabung menurun, dan AIDR 3D mungkin memiliki batasan dalam menghilangkan noise citra dan peningkatan kualitas citra subjektif dalam pengaturan dosis rendah.

Penulis telah melakukan studi pendahuluan dengan observasi di rumah sakit Islam Aisyiyah Malang yang menggunakan pesawat Toshiba, pemeriksaan MSCT abdomen yang dilakukan di rumah sakit berdasarkan pengamatan penulis menggunakan protokol abdomen rutin. AIDR 3D yang digunakan secara otomatis dengan setting standard tanpa pernah mengubah level dari AIDR 3D. Hal ini dikarenakan kurangnya pengetahuan Radiografer tentang rekonstruksi algoritma AIDR 3D, bahwa AIDR 3D terdapat pengaturan level strength yang dapat dipilih untuk menghasilkan kualitas citra optimal.

Berdasarkan hal tersebut diatas maka penulis tertarik untuk mengkaji secara teoritis tentang peranan penggunaan AIDR 3D pada MSCT abdomen dan menuangkannya dalam skripsi dengan judul "PERANAN ADAPTIVE ITERATIVE DOSE REDUCTION 3D (AIDR 3D) DALAM MENINGKATKAN KUALITAS CITRA MSCT ABDOMEN"

\section{Metode}

Jenis penelitian adalah penelitian deskriptif dengan metode Literature Review (Studi Literatur) tentang peranan Adaptive Iterative Dose Reduction $3 D$ pada peningkatan kualitas citra MSCT abdomen. Pengambilan data dalam penelitian ini dilaksanakan pada bulan April 2020 sampai dengan Mei 2020. Sedangkan metode penelitian yang digunakan penulis adalah kajian teori / studi literatur / studi pustaka. Studi literatur ini dimulai dari pencarian artikel dengan menggunakan kata kunci "AIDR 3D, Iterative Reconstruction, Image quality, Dose Radiation, Abdominal MSCT" di basis data (database) atau search engine yang berisi jurnal internasional yang kredibel. Basis data yang digunakan adalah ProQuest, Google Scholar, PubMed, SpringerLink, dan ScienceDirect. Pencarian dibatasi untuk jurnal yang diterbitkan pada tahun 2013 hingga 2020.

Jurnal-jurnal tersebut kemudian direduksi dengan menggunakan kriteria inklusi dan eksklusi. Adapun kriteria inklusi pada studi literatur ini adalah sebagai berikut :
1.Artikel ilmiah yang utuh, manuskrip dipandang utuh jika memuat judul, nama pengarang, penerbit, abstrak serta terdapat isi artikel yang lengkap hingga daftar pustaka.

2. Artikel yang dipilih adalah artikel yang dipublikasikan baik nasioal maupun internasional (dengan menggunakan bahasa inggris) antara tahun 2013-2020.

3. Artikel yang dipilih adalah artikel penelitian yang asli yang membahas tentang peranan AIDR 3D pada peningkatan kualitas citra MSCT abdomen, dan khususnya pada penggunaan variasi strength AIDR 3D.

4. Subyek penelitian di literatur pada manusia maupun phantom, dan akuisisi pemeriksaan pada MSCT abdomen.

Kriteria Eksklusi :

1.Artikel yang berupa review jurnal (artikel duplikat).

2.Repositori yang tidak dipublikasikan baik nasional maupun internasional. Artikel ilmiah yang yang belum memiliki DOI (Digital Object Identifier) adalah artikel yang belum dipublikasikan.

3. Subyek pada hewan atau anak-anak.

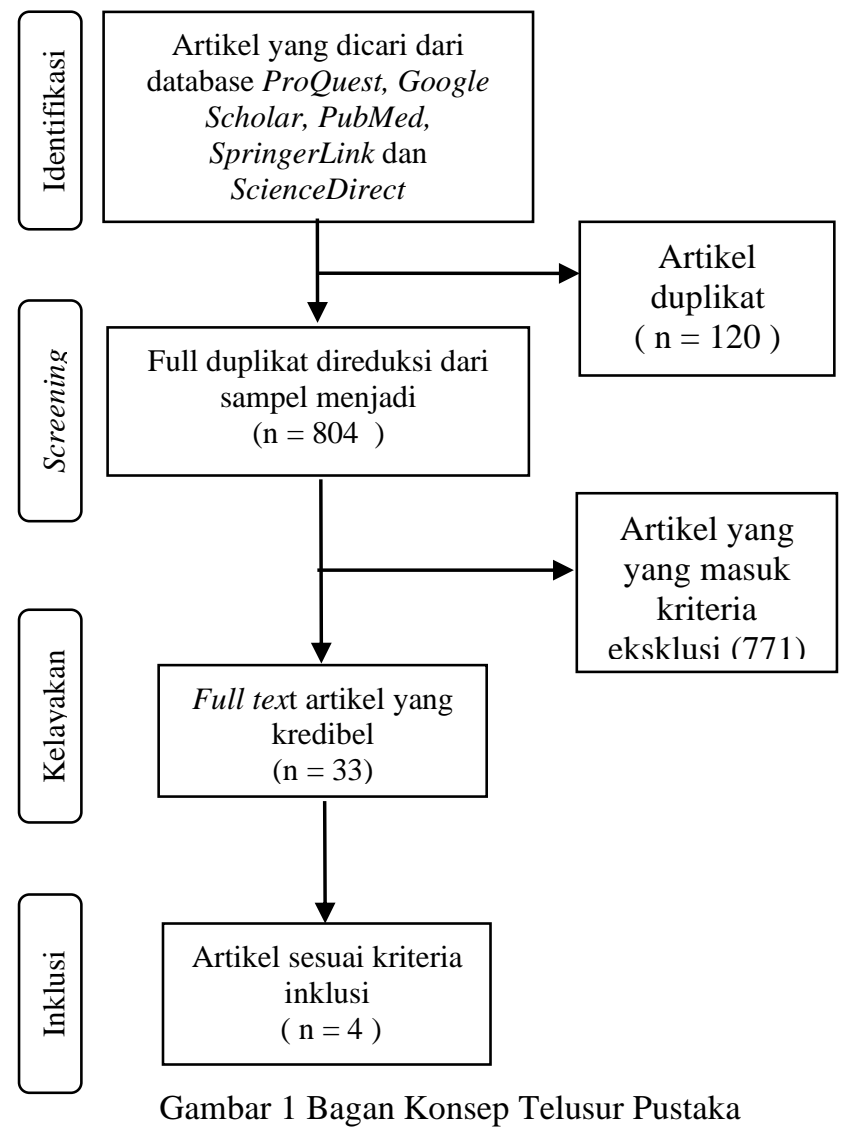

Setelah sumber/ bahan pustaka didapatkan maka selanjutnya peneliti merumuskan masalah 
dalam jurnal/ artikel yang didapatkan. Kemudian mengevaluasi dan mengkaji literatur atau buku secara kritis dan melakukan pengolahan data dengan membuat tabulasi deskripsi rangkuman jurnal yang meliputi judul jurnal, asal jurnal, nama penulis, tahun terbit, volume dan halaman jurnal, tujuan, metode, subjek penelitian, hasil studi, dan kesimpulan. Kemudian membuat persamaan dan perbedaan hasil masing-masing jurnal. Analisis data dilakukan dengan menggunakan rangkuman jurnal tersebut, kemudian analisis isi yang ada pada tujuan dan hasil temuan penelitian. Analisis isi jurnal akan mendapatkan persamaan dan perbedaan masing-masing jurnal. Mengevaluasi secara kritis, memberikan pendapat sehingga mudah ditarik kesimpulan untuk menjawab rumusan masalah dari studi ini sehubungan dengan peranan AIDR 3D pada kualitas citra MSCT abdomen. Kemudian memberikan saran pada akhir kajian.

\section{Hasil dan Pembahasan}

Penerapan AIDR 3D dapat mengurangi dosis CT pada pasien tergantung dari jenis pemeriksaan klinisnya, ukuran tubuh pasien, lokasi anatomis. AIDR 3D merupakan evolusi teknologi Iterative Reconstruction yang baru dari Toshiba, teknologi ini telah sepenuhnya terintegrasi ke dalam rantai pencitraan untuk mengoptimalkan pengurangan dosis dan meningkatkan kualitas citra. Hal ini dirancang untuk mengurangi dosis dengan cara mengurangi besarnya noise citra dengan tetap mempertahankan detail citra dan memungkinkan untuk akuisisi dosis yang lebih rendah (Toshiba, 2012).

Penulis melakukan pengkajian lebih mendalam tentang peranan Adaptive Iterative Dose Reduction $3 D$ pada peningkatan kualitas citra MSCT abdomen dengan melakukan studi literatur dari artikel atau jurnal penelitian yang meneliti tentang tingkat kekuatan AIDR 3D pada kualitas citra MSCT abdomen.

Dalam penelitian ini, penulis memaparkan informasi dari empat jurnal penelitian sebagai data yang akan digunakan untuk menjawab rumusan masalah penelitian. Empat jurnal tersebut memenuhi kriteria inklusi yang berhubungan dengan topik dan memiliki tahun terbit dari 2013 sampai 2016.

Hasil penelitian Chen dkk. (2016) pada analisis kuantitatif dari studi pasien, bahwa mean atenuasi ROI pada lobus kanan dan kiri hepar, aorta, dan musculus psoas tidak signifikan secara statistik untuk FBP atau AIDR 3D standard dan strong. Mean noise gambar paling rendah pada algoritma AIDR 3D strong pada semua studi dan pada dua subkelompok $\mathrm{D}_{\text {eff }}$ (Diameter Effective). Mean pengurangan noise pada semua ROI dengan algoritma AIDR 3D standard dan strong dengan FBP adalah $23,2 \%$ vs $34,6 \%, 16,2 \%$ vs $28,5 \%$, dan $35,2 \%$ vs $45,1 \%$, berurutan. Hal yang sama juga pada SNR yang lebih baik pada algoritma AIDR standard dan strong daripada FBP.

Sedangkan analisis kualitatif algoritma AIDR standard dan strong pada pasien dengan $\mathrm{D}_{\text {eff }}<29$ $\mathrm{cm}$ memiliki ketajaman citra dan artefak yang lebih baik daripada FBP, tetapi tidak pada kualitas citra dan noise. Sebaliknya, pada pasien dengan $D_{\text {eff }} \geq 29 \mathrm{~cm}$ memiliki ketajaman citra pada kualitas citra, noise, dan artefak. Untuk $D_{\text {eff }} \geq 29$ $\mathrm{cm}$, secara subjektif algoritma AIDR 3D strong memiliki noise citra yang lebih sedikit daripada algoritma AIDR 3D standard kecuali ketajaman citra pada pasien dengan $D_{\text {eff }}<29 \mathrm{~cm}$ seperti pada gambar 2 dan 3 di bawah ini :

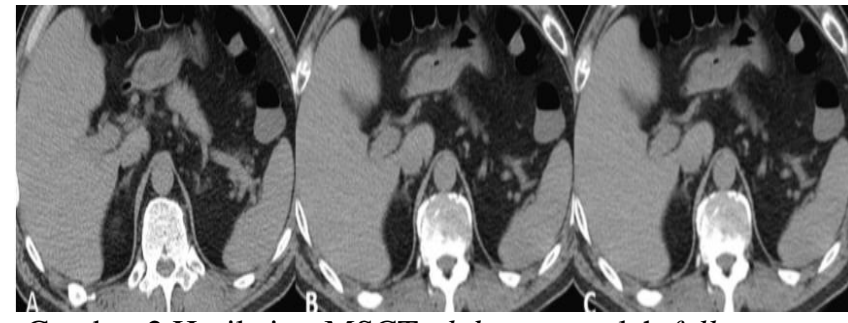

Gambar 2 Hasil citra MSCT abdomen setelah followup terapi Ca.colon (BB $80 \mathrm{~kg}$, BMI $27,7 \mathrm{~kg} / \mathrm{m}^{2}$, $D_{\text {eff }} 30 \mathrm{~cm}$ ) pada level porta dengan (A) FBP (B) AIDR 3D Standard, dan (C) AIDR 3D Strong. Rekonstruksi FBP menghasilkan noise citra yang lebih tinggi daripada AIDR 3D. Ketiga gambar tajam secara subyektif (Chen dkk., 2016)

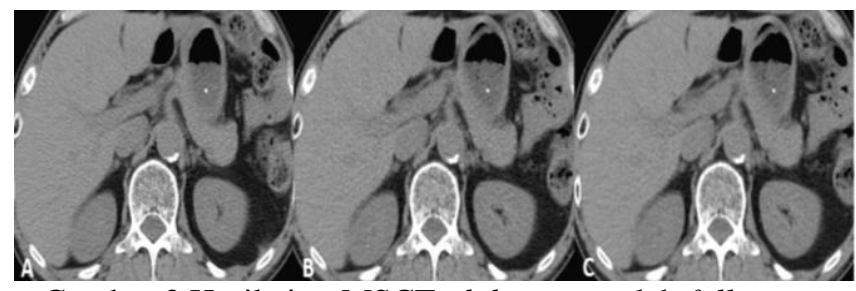

Gambar 3 Hasil citra MSCT abdomen setelah follow up terapi Ca.colon (BB 53kg, BMI 19,9 $\mathrm{kg} / \mathrm{m}^{2}, \quad D_{\text {eff }} 24 \mathrm{~cm}$ ) pada level porta dengan (A) FBP, (B) AIDR 3D standard, dan (C) AIDR 3D Strong. Kualitas citra keseluruhan AIDR 3D hampir sama dengan FBP, terdapat ketajaman citra subyektif yang sedikit kurang, terutama dengan AIDR 3D Strong namun infomasi diagnostik tidak terpengaruh (Chen dkk., 2016). 
Pada studi phantom AIDR 3D Mild menunjukkan pengurangan dosis 30\% daripada dengan FBP, dimana AIDR 3D Standard dan Strong menunjukkan pengurangan dosis $72 \%$. Sedangkan dosis radiasi pada studi pasien, penurunan dosis rata-rata dengan algoritma AIDR 3D pada subkelompok Deff $<29 \mathrm{~cm}$ dan $\geq 29 \mathrm{~cm}$ adalah $55,3 \%$ dan $32,8 \%$.

Algoritma AIDR 3D dapat mengurangi dosis radiasi dengan tetap menjaga kualitas citra. Kemampuan untuk mendeteksi lesi dengan kontras rendah memang sangatlah penting karena lesi pada organ solid abdomen termasuk liver biasanya menunjukkan kontras rendah. Dengan mempertimbangkan bahwa selain penggunaan algoritma IR, teknik Automatic Tube Current Modulation (ATCM) dan habitus tubuh pasien juga merupakan faktor penting yang mempengaruhi kemampuan dalam mendeteksi lesi lokal pada organ solid abdomen.

Hasil penelitian Yoon dkk. menunjukkan bahwa pada analisis kualitatif, noise citra dengan Half-Dose Mild, Standard dan Strong setara dengan citra akuisisi dengan Full-Dose FBP dari ketiga phantom. Namun, citra akuisisi dengan Quarth-Dose cenderung menunjukkan noise pada citra yang jauh lebih banyak daripada dengan citra akuisisi dengan Full-Dose FBP pada semua phantom kecuali citra rekonstruksi Strong.

Sedangkan pada evaluasi kuantitatif, citra dengan AIDR 3D mengalami penurunan noise daripada FBP pada semua phantom. Pengurangan noise dapat lebih bermakna ketika ukuran phantom meningkat dan ketika dosis radiasi menurun, seperti pada gambar 4 :

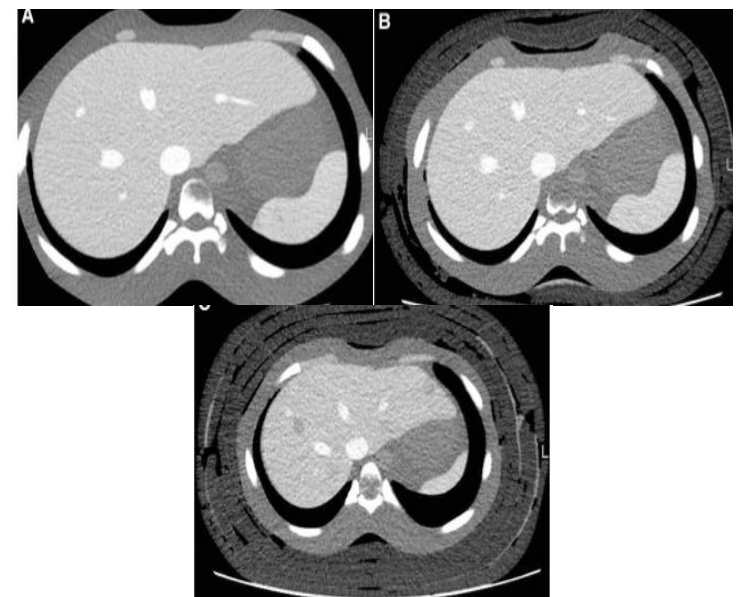

Gambar 4 CT scan pada phantom antropomorfik berbagai ukuran. (A) Gambar phantom ukuran kecil, (B) sedang (C) besar akuisisi dengan $120 \mathrm{kVp}$ Full-Dose, direkonstruksi menggunakan AIDR 3D Mild (Yoon dkk., 2014).

Kejelasan FLL kontras rendah bergantung pada dosis radiasi, algoritma rekonstruksi, dan ukuran phantom. Dari setiap kelompok dosis radiasi, kejelasan lesi FLL kontras rendah secara signifikan menurun karena dosis radiasi menurun pada phantom medium dan phantom besar daripada dengan FBP. Namun, dengan rekonstruksi AIDR 3D, citra dengan akuisisi dengan Half-Dose hampir sama daripada citra dengan akuisisi dengan Full-Dose FBP pada ketiga phantom. Pada grup Full-Dose FBP, kejelasan lesi menurun secara signifikan sejalan dengan peningkatan ukuran phantom. Hanya phantom ukuran besar yang menunjukkan peningkatan kejelasan FLL kontras rendah yang signifikan setelah rekonstruksi AIDR 3D dengan dengan Full-Dose, sedangkan phantom kecil dan sedang dengan rekonstruksi AIDR 3D menunjukkan kejelasan lesi yang serupa dengan gambar FBP dengan Full-Dose. Seperti pada gambar 5:

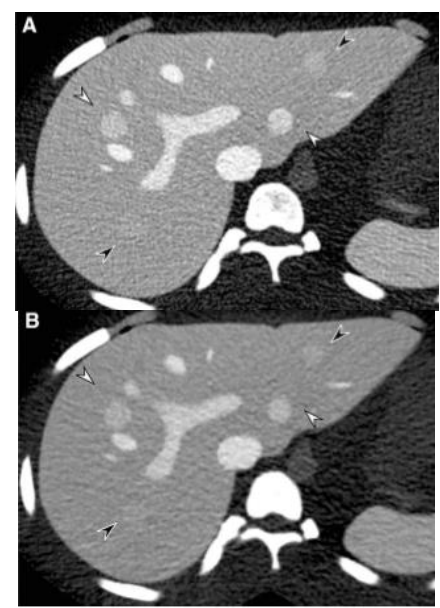

Gambar 5 Gambar CT phantom antropomorfik kecil. (A)FullDose FBP dan (B)Half-Dose Strong memperlihatkan dua FLL kontras rendah (panah hitam) dan kontras tinggi (panah putih) yang serupa (Yoon dkk., 2014)

Selain itu, jumlah FLL kontras rendah tak terlihat dinilai menurut berbagai tingkat kekuatan rekonstruksi. Jumlah FLL kontras rendah yang tak terlihat meningkat secara signifikan seiring penurunan dosis radiasi. Pada citra akuisisi dengan Half-Dose AIDR 3D dan Full-Dose FBP, jumlah FLL kontras rendah yang tidak terlihat bervariasi bergantung pada ukuran phantom. Pada phantom ukuran besar, jumlah lesi yang tidak terlihat melebihi 20\% pada citra dengan Full-Dose FBP, dan tingginya tingkat FLL yang tidak terlihat dapat 
diperbaiki setelah menerapkan AIDR 3D dengan rekonstruksi Standard dan dengan rekonstruksi Strong. Semua FLL kontras tinggi menunjukkan kejelasan lesi yang lebih baik daripada kontras rendah dalam kondisi pemindaian dan rekonstruksi yang sama.

Dalam semua phantom, dosis radiasi secara signifikan menurun dengan menggabungkan tingkat noise (SD) yang meningkat dan mengubah jenis pemindaian dari FBP ke Mild atau Standard, pengurangan DLP hingga $86,6 \%, 83,9 \%$, dan $78,6 \%$ pada phantom kecil, sedang, dan besar.

Teknik IR dapat mencapai penurunan dosis yang lebih baik daripada rekonstruksi FBP. Namun, beberapa peneliti telah mengalami masalah kualitas citra seperti tekstur buatan atau blotchy appereance ketika kekuatan tinggi IR digunakan. Secara teoritis, AIDR 3D dapat menurunkan dosis 50-75\%, terlepas dari ukuran tubuh pasien dan juga dapat memilih kekuatan IR yang berbeda untuk meningkatkan resolusi spasial.

Pada analisa kuantitaif, ketika FBP dan AIDR 3D digunakan dari tiga model phantom yang diperoleh dengan 8 nilai arus tabung yang berbeda (100-290 mA) dibandingkan untuk noise, SNR dan CNR, nilai-nilai noise dari citra yang direkonstruksi AIDR 3D lebih rendah daripada gambar FBP terlepas dari tingkat kekuatannya. Selain itu, rata-rata CNR dan SNR dari set gambar AIDR 3 D lebih tinggi daripada set gambar FBP.

Ketika AIDR 3D digunakan, terdapat perubahan relatif dalam noise, SNR dan CNR dalam persentase, mengkonfirmasi raw data serta semua parameter kuantitatif meningkat dengan pesat. SNR, CNR, dan penurunan noise yang lebih baik dicapai ketika algoritma rekonstruksi yang lebih kuat digunakan. Secara khusus, dalam model phantom $24 \mathrm{~cm}$, rata-rata penurunan noise citra $11,7 \%$, 22,6\%, dan 30,5\% dicapai menggunakan AIDR 3D masing-masing Mild, Sandard dan Strong.

Sedangkah dampak habitus tubuh pada efektivitas AIDR 3D untuk penurunan noise citra, AIDR 3D lebih efektif pada phantom denga ukuran $40 \mathrm{~cm}$ daripada dengan phantom ukuran $24 \mathrm{~cm}$ dan $30 \mathrm{~cm}$. Persentase penurunan noise AIDR 3D juga lebih besar pada phantom $30 \mathrm{~cm}$ daripada phantom $24 \mathrm{~cm}$. Persentase rata-rata penurunan noise dari pengaturan AIDR 3D Standard daripada FBP pada phantom $24 \mathrm{~cm}, 30 \mathrm{~cm}$, dan $40 \mathrm{~cm}$ masing-masing adalah $22,6 \%$, 35,9\%, dan $51,3 \%$. Mengenai penurunan noise, rekonstruksi algoritma AIDR 3D lebih efektif pada phantom berukuran lebih besar seperti pada gambar 6:

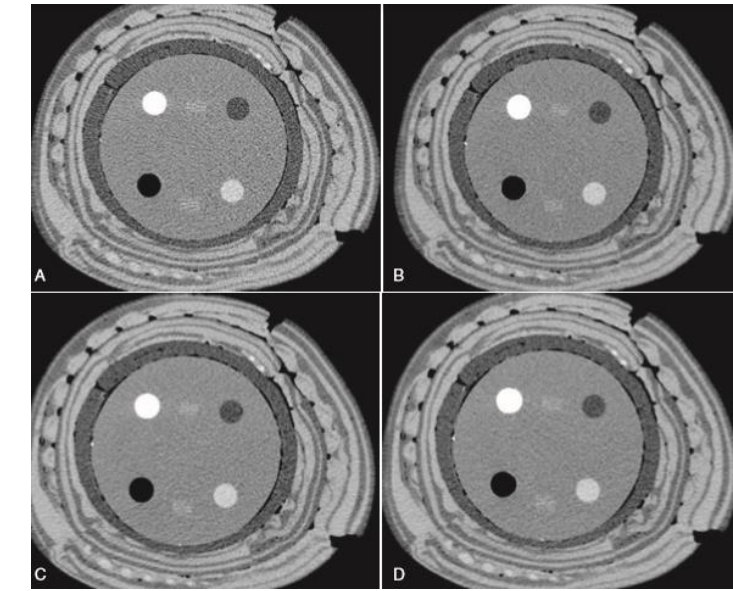

Gambar 6 Rekonstruksi CT dengan A) FBP B) AIDR

3D Mild C) AIDR 3D Standard C)

AIDR 3D Strong (Kim dkk., 2014)

Dampak algoritma AIDR 3D pada noise, lesi, dan kualitas citra berbeda menurut ukuran phantom dengan penilaian kualitatif. Noise meningkat secara signifikan dengan AIDR 3D daripada dengan FBP, walaupun kualitas citra keseluruhan berbeda secara signifikan antara FBP dan mode rekonstruksi AIDR 3D Strong saja. Selain itu, lesi conspicuity juga meningkat dengan pengaturan Standard dan Strong daripada FBP. Untuk model phantom ukuran $40 \mathrm{~cm}$, baik noise dan kualitas citra keseluruhan meningkat dengan penggunaan AIDR 3D Standrad dan Strong. Juga, khususnya, noise meningkat dengan semua algoritma AIDR 3D pada phantom ukuran $40 \mathrm{~cm}$. Sehubungan dengan lesi yang mencolok, ada peningkatan yang signifikan pada phantom $30 \mathrm{~cm}$ dengan algoritma AIDR 3D Standard dan Strong saja.

Pada dosis radiasi untuk CTDI $_{\mathrm{vol}}$ dan DLP dari CT scan pada masing-masing mAs berada dalam kisaran 12,2-35,1 mGy dan 362,8-1052 mGy•cm.

Dosis radiasi MSCT abdomen diharapkan dapat dikurangi menggunakan algoritma AIDR 3D dengan tetap menjaga kualitas citra. Namun, hanya sedikit laporan penelitian yang menyelidiki kualitas citra MSCT abdomen dosis rendah yang direkonstruksi dengan AIDR 3D. Nakamoto dkk. ingin mengetahui AIDR 3D dengan menggunakan tingkat kekuatan yang berbeda dengan FBP dalam dosis radiasi yang berbeda terhadap kualitas citra pada MSCT abdomen.

Noise dan CNR dari gambar dengan dosis standar dan dosis rendah menggunakan lima protokol rekonstruksi yang berbeda pada setiap pengaturan $\mathrm{kVp}$ dan $\mathrm{mA}$, AIDR 3D menghasilkan penurunan noise sebesar $8 \%-68 \%$ dan peningkatan CNR sebesar $8 \%-230 \%$ daripada dengan FBP. Pengurangan noise dan peningkatan CNR yang paling menonjol diantara empat kekuatan 
didapatkan pada AIDR 3D Strong. Pada pengaturan $120 \mathrm{kVp}$, noise dan CNR pada $100 \mathrm{~mA}$ dengan AIDR 3D Strong (masing-masing 6,1 dan 4,5) setara dengan pada $400 \mathrm{~mA}$ dengan FBP (masing-masing 6,7 dan 4,4). Pada pengaturan 80 $\mathrm{kVp}$, noise dan CNR pada $200 \mathrm{~mA}$ dengan AIDR 3D Strong (masing-masing 8,3 dan 4,5) setara dengan 580mA dengan FBP (masing-masing 10,2 dan 3,7).

Pada pengaturan $120 \mathrm{kVp}$, mean skor visual untuk kualitas citra pada $100 \mathrm{~mA}$ dengan AIDR 3D Strong dan Standard (masing-masing 4,5 dan 4,0) setara dengan gambar $400 \mathrm{~mA}$ dengan FBP $(4,0)$. Pada pengaturan $80 \mathrm{kVp}$, mean skor visual dari keseluruhan kualitas citra untuk 400 mA AIDR 3D Strong dan Standard (masing-masing 4,0 dan 4,0) setara dengan $580 \mathrm{~mA}$ dengan FBP $(4,5)$. Diagram kualitas citra secara keseluruhan dapat dilihat pada gambar 7:

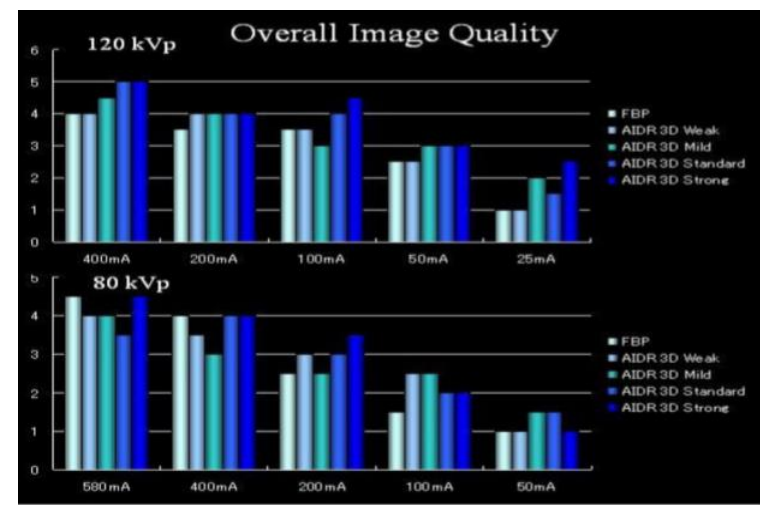

Gambar 7 Mean skor subjektif dari keseluruhan kualitas citra (Nakamoto dkk., 2013)

Pada pengaturan $120 \mathrm{kVp}$ noise objektif dan kualitas citra subjektif pada $100 \mathrm{~mA}$ dengan AIDR 3D Strong setara dengan FBP $400 \mathrm{~mA}$. Hasil ini menunjukkan bahwa penggunaan AIDR 3D pada pengaturan $120 \mathrm{kVp}$ dapat mengurangi dosis radiasi hingga $75 \%$ dengan tetap menjaga noise citra pada nilai yang dapat diterima. Pada pengaturan $80 \mathrm{kVp}$, kualitas citra subjektif pada $400 \mathrm{~mA}$ dengan AIDR 3D Strong setara dengan FBP $580 \mathrm{~mA}$, meskipun noise citra objektif pada pengaturan $200 \mathrm{~mA}$ dengan AIDR 3D Strong setara dengan yang FBP 580mA. Jadi, pengurangan dosis pada pengaturan $80 \mathrm{kVp}$ akan tetap berada pada kisaran 31-66\%.

\section{Peranan AIDR 3D pada peningkatan kualitas citra MSCT abdomen}

MSCT Abdomen merupakan pencitraan multiphase untuk menilai organ dan kelainan patologi pada fase arteri, fase vena dan fase delay dalam penyangatan kontras. Penggunaan MSCT Abdomen multiphase ini menambah informasi diagnostik juga menambah paparan radiasi kepada pasien karena dilakukan scanning beberapa kali. Protokol MSCT terbaru dirancang untuk menekan dosis radiasi menjadi serendah mungkin untuk mendapatkan citra yang dapat terima. Penurunan dosis radiasi akan menghasilkan noise, sehingga akan menghasilkan citra dengan kualitas yang rendah (Nikolaou dkk., 2019). Menurut Seeram (2016) semakin tinggi nilai noise maka dapat dikatakan bahwa kualitas citra akan menurun.

Menurut Seeram (2016), salah satu metode untuk mengurangi noise adalah dengan menggunakan Iterative Reconstruction (IR). IR merupakan teknologi CT scan yang berkonsentrasi pada penyangatan kualitas citra, dimana IR sendiri merupakan rekonstruksi algoritma dan merupakan filter rekonstruksi pengurangan noise yang membantu mempertahankan kualitas citra tanpa kehilangan kejelasan gambar struktur anatomi.

AIDR 3D merupakan Teknik IR yang diperkenalkan oleh Toshiba Medical Systems. AIDR 3D ini termasuk rekonstruksi algoritma yang bekerja pada raw data domain dan image space data dengan pengaturan level Strong, Standard, dan Mild (Toshiba, 2012). Dalam studi ini penulis menganalisis peranan dari AIDR 3D pada MSCT abdomen terhadap kualitas citra berdasarkan kajian jurnal, kualitas citra yang dimaksud dalam studi ini meliputi evaluasi noise, SNR, CNR, artefak dan ketajaman citra (sharpness).

Chen dkk. (2016) mengevaluasi performa dari AIDR 3D dan FBP dengan menguji ketiga kekuatan dan hasilnya bahwa AIDR 3D Strong memiliki potensi pengurangan noise terbesar dan meningkatkan SNR tertinggi daripada kekuatan lainnya maupun FBP. Hasil ini juga serupa dengan hasil penelitian Kim dkk. (2014), Nakamoto dkk. (2013) bahwa AIDR 3D mampu menurunkan noise citra secara signifikan, Meningkatkan SNR dan CNR pada phantom tanpa degradasi kualitas citra, menurunkan noise terbanyak dan meningkatkan SNR dan CNR tertinggi pada kekuatan AIDR 3D Strong. Begitu juga Yoon dkk. (2014) menunjukkan bahwa noise citra, kualitas citra, dan kejelasan lesi FLL kontras rendah dapat ditingkatkan dengan menerapkan AIDR 3D pada ketiga phantom ukuran berbeda dengan dosis radiasi yang sama. Hasil penelitian diatas sesuai dengan penelitian sebelumnya tentang algoritma IR. Juga menunjukkan bahwa AIDR 3D dapat 
mengurangi noise citra serta meningkatkan SNR dan CNR (Gervaise dkk., 2012).

Penurunan noise ini terjadi karena proses IR yang terdapat pada AIDR 3D. Menurut Toshiba (2012), proses IR pada AIDR 3D ini untuk memperbaiki karakteristik noise dalam ruang proyeksi, jumlah foton dianalisis pada tiap posisi dalam raw data, dan algoritma adaptif diterapkan berdasarkan teknik statistik dan model scanner yang canggih. Komponen raw data space dapat mempertahankan kualitas spasial resolusi dengan mengurangi besarnya noise secara keseluruhan, serta manifestasi dari noise struktural pada gambar yang disebabkan karena jumlah foton yang rendah, seperti streak artifact. Komponen reduksi noise berbasis voxel dalam image space beradaptasi untuk menonjolkan gradien voxel, sehingga dapat mengurangi besarnya noise pada setiap ulangan rekonstruksi, sambil tetap mempertahankan detail gambar seperti misalnya garis dan tepi. Dalam setiap ulangan, AIDR 3D memperbaiki hasil ini pada pemeriksaan khusus, sehingga menyeimbangkan hubungan antara pengurangan noise dan terjaganya spasial resolusi.

Penurunan noise ini sesuai dengan teori yang disebutkan oleh Nikolaou dkk. (2019), noise citra mengalami penurunan berdasarkan peningkatan level kekuatan dari IR, dimana pada level IR noise citra mengalami penurunan noise dibandingkan dengan rekonstruksi tanpa IR. Menurut Feger dkk. (2015), juga menyebutkan perubahan penggunaan AIDR 3D menghasilkan penurunan noise dan peningkatan SNR dan CNR seiring dengan kenaikan level strength. Dan pada teori (Seeram, 2016) memaparkan bahwa telah ada "peningkatan yang mengesankan" dalam pengurangan noise dari $-7 \%$ menjadi $-50 \%$, dan dalam kualitas citra menggunakan AIDR 3D.

Berdasarkan hasil data literatur juga diketahui nilai noise akan mempengaruhi artefak, visibiltas lesi atau ketajaman citra. Dimana hasil gambaran dengan AIDR 3D memberikan visibiltas lesi atau ketajaman citra yang lebih baik daripada FBP. Hal ini dikarenakan adanya penggunaan rekonstruksi algoritma AIDR 3D, dimana AIDR 3D ini merupakan teknik IR yang berkonsentrasi pada penyangatan citra.

Penurunan noise yang lebih besar tidak mengakibatkan penurunan ketajaman citra. Ketajaman citra dan kualitas citra secara keseluruhan lebih baik pada AIDR 3D Strong daripada dengan AIDR 3D standard pada studi phantom dengan ukuran $30 \mathrm{~cm}$ oleh Kim dkk. (2014). Hal ini sesuai dengan hasil penelitian Feger dkk. (2015) yang meneliti tentang pengaruh tingkat kekuatan AIDR 3D pada CTA Coronaria.

Menurut penulis, hasil gambaran AIDR 3D lebih tampak halus (smooth), namun ketajaman (sharpness) citra tetap optimal, dan kejelasan dari struktur anatominya tetap optimal. Hal ini sesuai dengan teori menurut Toshiba (2012), Seeram (2016), Nikolaou dkk. (2019) dimana dengan penggunaan teknik Iterative Reconstruction (IR) mampu mengurangi noise, namun tetap mempertahankan kualitas citra tanpa kehilangan detail penggambaran struktur anatomi. Menurut Seeram (2016), semakin tinggi nilai noise maka dapat dikatakan bahwa kualitas gambaran CT scan akan menurun. Selain itu, menurut Toshiba (2012), rekonstruksi AIDR 3D mempertahankan informasi diagnostik, spasial resolusi, dan tekstur gambar dengan membuang noise, bukan hanya dengan cara menghaluskannya. Meskipun menghaluskan gambar dapat mengurangi noise, teknik ini juga dapat menghaluskan bagian tepi, menurunkan spasial resolusi, dan mungkin menghaluskan informasi diagnostik penting.

Penulis sepakat bahwa peranan AIDR 3D pada kualitas citra MSCT abdomen pada dasarnya sama pada empat penelitian diatas yang menyatakan bahwa AIDR 3D dapat mengurangi noise citra objektif dan artefak serta meningkatkan CNR, SNR, dan ketajaman (sharpness) pada seluruh pengaturan $\mathrm{kVp}$ dan $\mathrm{mA}$. Pengurangan noise dan peningkatan CNR, SNR yang paling menonjol didapatkan pada AIDR 3D Strong, dikuti dengan Standard dan Mild. Kualitas citra dioptimalkan dengan menggunakan level Strong pada AIDR 3D tertinggi untuk kedua SNR dan CNR, dengan mengurangi noise yang paling efisien. Dengan demikian, bila digunakan pada dosis radiasi yang sama, merekonstruksi dengan AIDR 3D Strong akan menghasilkan kualitas citra yang lebih baik.

\section{Peranan penggunaan AIDR 3D dalam pengurangan dosis radiasi MSCT abdomen}

Secara keseluruhan berdasarkan hasil dari keempat penelitian diatas, penggunaan AIDR 3D pada MSCT abdomen dapat menurunkan dosis radiasi yang signifikan. Pengurangan dosis radiasi yang dilaporkan bervariasi dari 23\% hingga 76\%, dengan kualitas citra tetap terjaga.

Performa AIDR 3D menggunakan pengurangan dosis yang lebih besar atau lebih kecil telah dianalisa oleh peneliti tersebut diatas, berbagai pengurangan dosis yang dicapai sebagian dapat dijelaskan oleh perbedaan dalam indeks 
massa tubuh (BMI). Misalnya, pada hasil jurnal I / Chen dkk. (2016) menemukan penurunan dosis rata-rata dengan algoritma AIDR 3D pada subkelompok Deff $<29 \mathrm{~cm}$ dan $\geq 29 \mathrm{~cm}$ adalah $55,3 \%$ dan $32,8 \%$, berurutan. Karena atenuasi radiasi pengion lebih menonjol pada pasien dengan nilai BMI lebih tinggi, pengurangan dosis lebih sedikit dapat dicapai pada pasien ini. Namun, noise juga bisa bermasalah dalam pasien dengan BMI normal dan rendah. Karena evaluasi organ abdomen mungkin rumit karena jumlah yang lebih kecil dari lemak intraabdomen. Oleh karena itu, pengurangan dosis yang dapat dicapai juga terbatas pada pasien kecil.

Begitu juga pada jurnal II / Yoon dkk. (2014), peningkatan kualitas citra oleh AIDR 3D memungkinkan pengurangan pada dosis radiasi hingga 50\%, dengan kualitas citra yang tetap setara dengan citra FBP pada dosis penuh. Pengulangan dosis radiasi dari Sure Exposure 3D, yang dapat menyesuaikan arus tabung untuk mencapai kualitas citra target dengan parameter akuisisi arus tabung untuk mencapai kualitas citra target dengan parameter akuisisi dan rekonstruksi yang berbeda. Hal ini juga memiliki fitur unik karena sepenuhnya terintegrasi dengan AIDR 3D (Geleijns \& Irwan, 2012), dan karena AIDR 3D digunakan bersama dengan program Sure Exposure, program ini dapat menyederhanakan alur kerja dan secara teori tidak akan terlalu terpengaruh oleh penghalusan gambar dengan pengurangan dosis radiasi (Gervaise dkk., 2012).

Dan hasil jurnal IV / Nakamoto dkk. (2013) juga menyimpulkan penggunaan AIDR 3D pada pengaturan $120 \mathrm{kVp}$ memungkinkan pengurangan dosis radiasi hingga $75 \%$ dengan tetap menjaga noise citra pada nilai yang dapat diterima. Pada pengaturan $80 \mathrm{kVp}$, kualitas citra subjektif pada $400 \mathrm{~mA}$ dengan AIDR 3D Strong setara dengan FBP $580 \mathrm{~mA}$, meskipun noise citra objektif pada pengaturan $200 \mathrm{~mA}$ dengan AIDR 3D Strong sebanding dengan yang FBP $580 \mathrm{~mA}$. Jadi, pengurangan dosis pada pengaturan $80 \mathrm{kVp}$ akan tetap berada pada kisaran 31-66\%. Sedangkan pada hasil penelitian jurnal III / Kim dkk., (2014), hanya menyatakan dosis antara penggunaan AIDR 3D dan FBP bahwa CTDI $_{\text {vol }}$ dan DLP masing-masing mAs berada dalam kisaran 12,2-35,1 mGy dan 362,8-1052 $\mathrm{mGy}{ }^{\bullet} \mathrm{cm}$, masing-masing.

Berdasarkan empat penelitian diatas penulis sepakat bahwa AIDR 3D yang terintegrasi ${ }^{S U R E}$ Exposure $3 D$ memungkinkan reduksi otomatis dosis radiasi dengan tetap mempertahankan kualitas citra pada pengaturan dosis rendah.
Pengurangan dosis radiasi yang dilaporkan bervariasi dari $31 \%$ hingga $75 \%$, dengan kualitas citra tetap terjaga. Hal ini sesuai dengan teorinya (Geleijns \& Irwan, 2012), dan juga sesuai dengan beberapa penelitian yang dilakukan oleh beberapa peneliti dengan jenis pemeriksaan yang berbeda. Seperti penelitian Rodrigues dkk. (2016) menghasilkan rekonstruksi AIDR 3D mampu menurunkan dosis radiasi hingga $75 \%$ pada pemeriksaan CT Coronary artery calcium scoring.

Penurunan dosis radiasi pada penggunaan AIDR 3D dikarenakan penggunaan AIDR 3D pada secara khusus dirancang untuk bekerja secara iterative pada dimensi data rekostruksi dan raw data. Proses AIDR 3D menghasilkan pengurangan noise yang kuat, yang sangat penting untuk untuk pencapaian pemeriksaan dosis sangat rendah dalam pencitraan CT. Integrasi teknologi pengurangan dosis adalah penting untuk manajemen dosis optimal. Oleh karena itu AIDR 3D telah terintegrasi dengan Sure Exposure 3D. Kombinasi ini memberikan solusi yang baik untuk manajemen dosis yang kuat, karena dapat menghitung paparan radiasi minimum yang diperlukan untuk pemeriksaan pada setiap pasien, hal ini sesuai teori dari Tack dkk. (2012).

Penulis setuju bahwa penggunaan AIDR 3D dapat berpengaruh terhadap kualitas citra pengurangan artefak. Dengan demikian, adalah mungkin untuk menggunakan parameter akuisisi tingkat yang lebih rendah dan karena itu mengurangi dosis untuk pasien. Dalam pandangan penulis penggunaan AIDR 3D dapat mengurangi dosis radiasi MSCT abdomen, berkurang antara $31 \%$ hingga $75 \%$. Temuan positif ini konsisten dengan prinsip ALARA (As Low As Reasonably Achievable / dosis serendah mungkin yang dapat dicapai secara optimal) dimana paparan radiasi serendah mungkin harus diterapkan di semua pemeriksaan radiasi pengion tanpa mengurangi kualitas citra (Seeram, 2016).

\section{Simpulan}

Peranan AIDR 3D dapat meningkatkan kualitas citra MSCT abdomen dengan mengurangi noise dan artefak serta meningkatkan CNR, SNR ketajaman citra dan peranan penggunaan AIDR 3D yang terintegrasi ${ }^{S U R E}$ Exposure $3 D$ dapat mengurangi dosis radiasi yang lebih baik tanpa mengurangi kualitas citra. Pengurangan dosis radiasi antara $23 \%$ hingga $76 \%$. 


\section{Daftar Pustaka}

Chen, C. M., Lin, Y. Y., Hsu, M. Y., Hung, C. F., Liao, Y. L., \& Tsai, H. Y. (2016). Performance of adaptive iterative dose reduction 3D integrated with automatic tube current modulation in radiation dose and image noise reduction compared with filtered-back projection for $80-\mathrm{kVp}$ abdominal CT: Anthropomorphic phantom and patient study. European Journal of Radiology. https://doi.org/https://doi.org/10.1016/j.ejrad.20 16.07.002

Feger, S., Rief, M., Zimmermann, E., Martus, P., Schuijf, J. D., Blobel, J., Richter, F., \& Dewey, M. (2015). The impact of different levels of adaptive iterative dose reduction $3 \mathrm{D}$ on image quality of 320-row coronary CT angiography: A clinical trial. PLoS ONE, 10(5), 1-16. https://doi.org/10.1371/journal.pone.0125943

Geleijns, J., \& Irwan, R. (2012). Practical Approaches to Dose Reduction: Toshiba Perspective. 633-645. https://doi.org/https://doi.org/10.1007/174_2011 501

Gervaise, A., Osemont, B., Lecocq, S., Noel, A., Micard, E., Felblinger, J., \& Blum, A. (2012). CT image quality improvement using adaptive iterative dose reduction with wide-volume acquisition on 320-detector CT. European Radiology, 22(2), 295-301. https://doi.org/10.1007/s00330-011-2271-7

Kim, M., Lee, J. M., Yoon, J. H., Son, H., Choi, J. W., Han, J. K., \& Choi, B. I. (2014). Adaptive iterative dose reduction algorithm in CT: Effect on image quality compared with filtered back projection in body phantoms of different sizes. Korean Journal of Radiology. https://doi.org/10.3348/kjr.2014.15.2.195

Lampignano, J. P., \& Kendrick, L. E. (2018). Radiographic Positioning and Realated Anatomy.

Matsuki, M., Murakami, T., Juri, H., Yoshikawa, S., \& Narumi, Y. (2013). Impact of adaptive iterative dose reduction (AIDR) 3D on low-dose abdominal CT: Comparison with routine-dose CT using filtered back projection. Acta Radiologica. https://doi.org/10.1177/0284185113488576

Nakamoto, A., Kim, T., Hori, M., Onishi, H., Tatsumi, M., Tsuboyama, T., \& Tomiyama, N. (2013). Low-dose abdominal CT using adaptive iterative dose reduction $3 D$ ( AIDR $3 D$ ): Evaluation of radiation dose and image quality with an anthropomorphic phantom.

Nikolaou, K., Bamberg, F., Laghi, A., \& Rubin, G. D. (2019). Multislice CT (Fourth Edi). https://doi.org/10.1259/bjr/19919145

Rodrigues, M. A., Williams, M. C., Fitzgerald, T., Connell, M., Weir, N. W., Newby, D. E., Van Beek, E. J. R., \& Mirsadraee, S. (2016). Iterative reconstruction can permit the use of lower X-ray tube current in CT coronary artery calcium scoring. British Journal of Radiology, 89(1064), $1-10$. https://doi.org/10.1259/bjr.20150780

Scharf, M., Brendel, S., Melzer, K., Hentschke, C., May, M., Uder, M., \& Lell, M. M. (2017). Image quality, diagnostic accuracy, and potential for radiation dose reduction in thoracoabdominal CT, using Sinogram Affirmed Iterative Reconstruction (SAFIRE) technique in a longitudinal study. PLOS ONE, 12(7), $1-13$. https://doi.org/10.1371/journal.pone.0180302

Seeram, E. (2016). COMPUTED TOMOGRAPHY Physical Principles, Clinical Applications, and Quality Control FOURTH EDITION. http://evolve.elsevier.com/Seeram/YOU'VEJU STPURCHASED

Tack, D., K.Kalra, M., \& Gevonois, P. A. (2012). Radiation Dose from Multidetector CT (Second Edi). https://doi.org/10.1007/978-3-540-853817

Toshiba, M. S. (2012). AIDR 3D Iterative Reconstruction: Integrated, Automated and Adaptive Dose Reduction. White Paper, 1-10. Yoon, J. H., Lee, J. M., Hur, B. Y., Baek, J., Shim, H., Han, J. K., \& Choi, B. I. (2014). Influence of the adaptive iterative dose reduction $3 D$ algorithm on the detectability of low-contrast lesions and radiation dose repeatability in abdominal computed tomography: a phantom study. https://doi.org/10.1007/s00261-014- 